\title{
Radiation-Tolerance Assessment of a Redundant Wireless Device
}

\author{
Q. Huang, Member, IEEE and J. Jiang, Fellow, IEEE
}

\begin{abstract}
This paper presents a method to evaluate radiationtolerance without physical tests for a commercial off-the-shelf (COTS)-based monitoring device for high level radiation fields, such as those found in post-accident conditions in a nuclear power plant (NPP). This paper specifically describes the analysis of radiation environment in a severe accident, radiation damages in electronics, and the redundant solution used to prolong the life of the system, as well as the evaluation method for radiation protection and the analysis method of system reliability. As a case study, a wireless monitoring device with redundant and diversified channels is evaluated by using the developed method. The study results and system assessment data show that, under the given radiation condition, performance of the redundant device is more reliable and more robust than those nonredundant devices. The developed redundant wireless monitoring device is therefore able to apply in those conditions (up to $10 \mathrm{M}$ Rad (Si)) during a severe accident in a NPP.
\end{abstract}

Index Terms - COTS, radiation-tolerance assessment, radhardened by design

\section{INTRODUCTION}

$\mathrm{S}_{\mathrm{s}}^{\mathrm{B}}$ EMICONDUCTOR-BASED electronic s ystems ar e h ighly susceptible to high energy particles present in strong radiation fields, such as those in aeronautics and space sectors, nuclear $\mathrm{p}$ ower $\mathrm{p}$ lants, an $\mathrm{dt}$ he $\mathrm{n}$ uclear warfare. $\mathrm{T}$ aken Fukushima Daiichi nuclear disaster as an example, one of the lessons learnt is the level of difficulty to obtain environmental conditions inside the plant due to the presence of large amount of radioactive substances, which can cau se damages to semiconductor based devices and systems. One approach to levitate such a $\mathrm{p}$ roblem i $\mathrm{st}$ o em ploy $\mathrm{r}$ adiation $\mathrm{h}$ ardened ( $\mathrm{rad}-$ hardened) $\mathrm{d}$ evices $\mathrm{i} \mathrm{n}$ such $\mathrm{s}$ ystems. $\mathrm{P}$ reliminary an alysis indicates, however, that $\mathrm{t}$ his ap proach is prohibitively expensive. Furthermore, many new data processing algorithms and co mmunication $t$ echnologies $r$ equire de vices $t$ o $s$ upport high speed, large storage, and low power consumption. Radhardened devices may not even meet those advanced system requirements. Another a pproach i s t or ely on $r$ egular commercial o ff-the-shelf ( COTS) d evices, but to u tilize radhardened $t$ echniques $t$ o $r$ educe the $v$ ulnerability of $r$ adiation effects and to prolong the life of the system during the mission of the deployment. One approach is to take advantage of the triplication of important circuits and subsystems to detect and

The a uthors a rew ith $\mathrm{t}$ he $\mathrm{D}$ epartment o fE lectrical an $\mathrm{d}$ Computer Engineering, The University of Western Ontario, London, Ontario, N6A 5B9, Canada (e-mail: jiiang@eng.uwo.ca). to correct radiation in duced errors. $\mathrm{N}$ eedless $\mathrm{t}$ o $\mathrm{s}$ ay, $\mathrm{t}$ he assessment of the radiation-tolerance is a critical step in such design.

In general, the performance of rad-hardened systems can be evaluated in two ways: (1) physical tests: which uses external perturbation s ources ( natural an $\mathrm{d}$ accel erated $\mathrm{p}$ article radiation, 1 aser b eam, $\mathrm{p}$ in forcing, et c.) t o cr eate a $\mathrm{s}$ imilar radiation en vironment $t$ o ev aluate $t$ he $p$ erformance $o f t$ he design. This approach is very precise but could be excessively complicated and expensive; and (2) simulation with a nalysis: which u ses lo gic relationships of the circuits a nd systems to access i nternal el ements a nd i nsert the ef fect of a $\mathrm{r}$ adiation induced $f$ ault a ccording to th e f ault model. $H$ owever, a limitation of this a pproach is that it i s difficult to a ssess the radiation-tolerance of the whole system [1]. To address these issues, a new approach by combining the radiation protection and the rad-hardened design is developed. To demonstrate this method, a wireless monitoring d evice is d eveloped for $\mathrm{h}$ igh level radiation fields during a s erve accident in nuclear power plants.

The $r$ eminder of t he $\mathrm{p}$ aper is o rganized a s follows. P ostaccident en vironments, $r$ adiation $d$ amages o $n$ el ectronics, as well as potential solutions are described in detail in Section II with the p roblem statement. S ubsequently, the e valuation of radiation $\mathrm{p}$ rotection $\mathrm{s}$ cheme is d iscussed in $\mathrm{S}$ ection I II. The radiation-tolerance as sessment of a redundant architecture is discussed in S ection I V. F inally, using a wireless monitoring device as an example, the implementation and the assessment of its radiation-tolerance are presented in Section V.

\section{ANALYSIS OF RADIATION DAMAGES}

\section{A. Post-Accident Environments in NPPs and Radiation Effects on Electronics}

In the e vent of a nuclear accident, a significant a mount of radiation can be released, which may include al pha $(\alpha)$, beta $(\beta)$ particles, gamma $(\gamma)$ rays, $x$-rays, and neutron particles [2]. Taken Fukushima Daiichi disaster as an example, in February 2017 , the level of radiation particles from melted fuel has been estimated up t o $530 \mathrm{~Sv} / \mathrm{h}$ inside the c ontainment o f 0.2 reactor [3]. This le vel of radiation is so hi gh that $\mathrm{c}$ an cause severe damages to electronic devices if deployed there.

In general, radiation particles lose their energy through either non-ionization processes (displacement damage) and/or ionization processes when they pa ss through s emiconductor devices. $\mathrm{R}$ adiation ef fects o $\mathrm{n}$ el ectronics can generally be classified into three categories: 
(1) Displacement damage (DD), which is caused by longterm $n$ on-ionizing ef fects, when $i$ ncident $p$ articles have enough energy to knock an atom free from its normal lattice structure in the semiconductor and onto an interstitial site. It will ch ange $\mathrm{p}$ roperties of the $\mathrm{d}$ evice an $\mathrm{d} l$ ead to permanent damage [4];

(2) Total io nizing d ose ( TID), which $r$ efers to the to tal amount of e nergy de posited by the particles passing through semiconductor materials. I $\mathrm{t}$ is a $\mathrm{n}$ i mportant $\mathrm{c}$ onsideration when s emiconductors $\mathrm{d}$ evices ar e ex posed $\mathrm{t}$ o a s trong radiation environment [5]; and

(3) Single ev ent e ffect ( SEE), which is p rimarily cau sed by single particle ionization and/or s econdary particle formation. According $t \quad o$ the failure mechanism of semiconductor materials, a single event e ffect can further be divided into two types: (1) non-destructive effects, which can be $r$ ecovered $b$ y $p$ erforming a $s$ ystem $r$ eset, o $r d$ ata $r$ einitialization, i ncluding single e vent $t$ ransient ( SET), s ingle event up set ( SEU), a nd s ingle e vent functional i nterrupt (SEFI); an d (2) d estructive effects, which ar e t erminal a nd cannot b e r ecovered, i ncluding single e vent 1 atchup ( SEL), single event snapback (SES), single event burnout (SEB), and single event gate rupture (SEGR) [6].

This work mainly focuses on the damages due to ionizing radiation. Displacement damages are therefore not considered. Considering short-term radioactive release (less than 24 hours) in each stage of a nuclear ac cident [7], it is assumed that the post-accident monitoring devices have to survive the first 24 hours of the accident. Taking the highest level of radiation in the F ukushima acci dent ( $530 \mathrm{~Sv} / \mathrm{h}$ ) a s the radiation $\mathrm{r}$ ate, the total radiation dose after the first 24 hours can be obtained as follows:

$$
R=530 S v / h \times 24 h=12720 S v=1272.0 \mathrm{~K} \mathrm{Rad}(\mathrm{Si}) .
$$

Total radiation dose (10 $\mathrm{M} \mathrm{Rad}(\mathrm{Si})$ ) are considered as the limit in this work.

\section{B. A Potential Solution}

1) Radiation Protection to Mitigate Damages of Total Dose

As s hown i n F ig.1, most $\mathrm{s}$ emiconductor de vices will experience radiation damages when the total radiation dose is more than $20 \mathrm{~K} \mathrm{Rad}(\mathrm{Si})(1 \mathrm{~Gy}=100 \mathrm{Rad}(\mathrm{Si}))$ [8]. Electronic systems made with regular COTS components will definitely be damaged if it is directly exposed to a radiation environment whose total dose is $10 \mathrm{M}$ Rad ( $\mathrm{Si}$ ). Radiation protection is an effective solution to mitigate radiation damages for the to tal dose. The reliability and the lifespan of electronic systems are determined $b$ y the $t$ ype of radiation it is e xposed to, th $\mathrm{e}$ radiation $\mathrm{r}$ esistance of it $\mathrm{s} s$ emiconductors, and the properties of the $\mathrm{s}$ hielding $\mathrm{m}$ aterials used [9]. In th is work, $\mathrm{r}$ adiation protection i s u sed where ev er $n$ ecessary to r educe th e to tal dose to less than $20 \mathrm{~K} \operatorname{Rad}(\mathrm{Si})$.

\section{2) Radiation Protection to Mitigate Damages of Total Dose}

On $\mathrm{t}$ he ot her $\mathrm{h}$ and, $\mathrm{r}$ adiation $\mathrm{s}$ hielding i s not e ffectively against single e vent e ffects [10]. S ince system recovery and

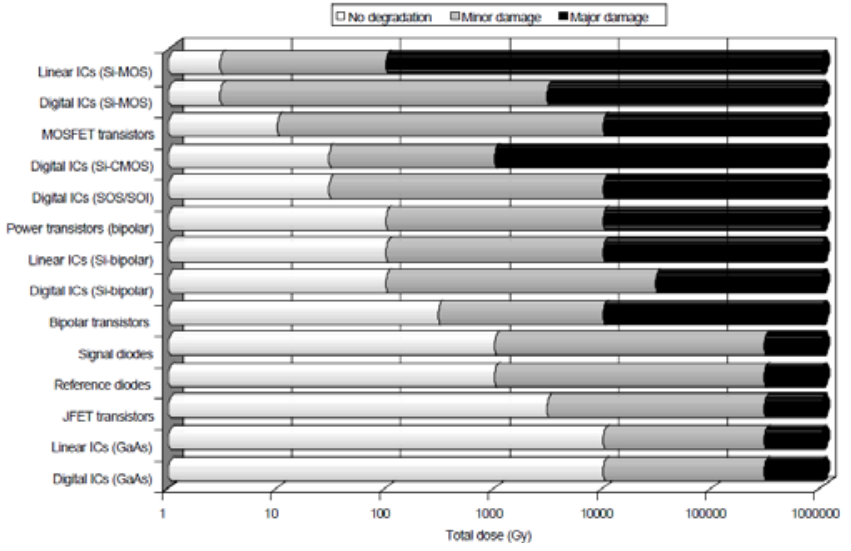

Fig. 1. Radiation tolerance by a family of COTS components [8]

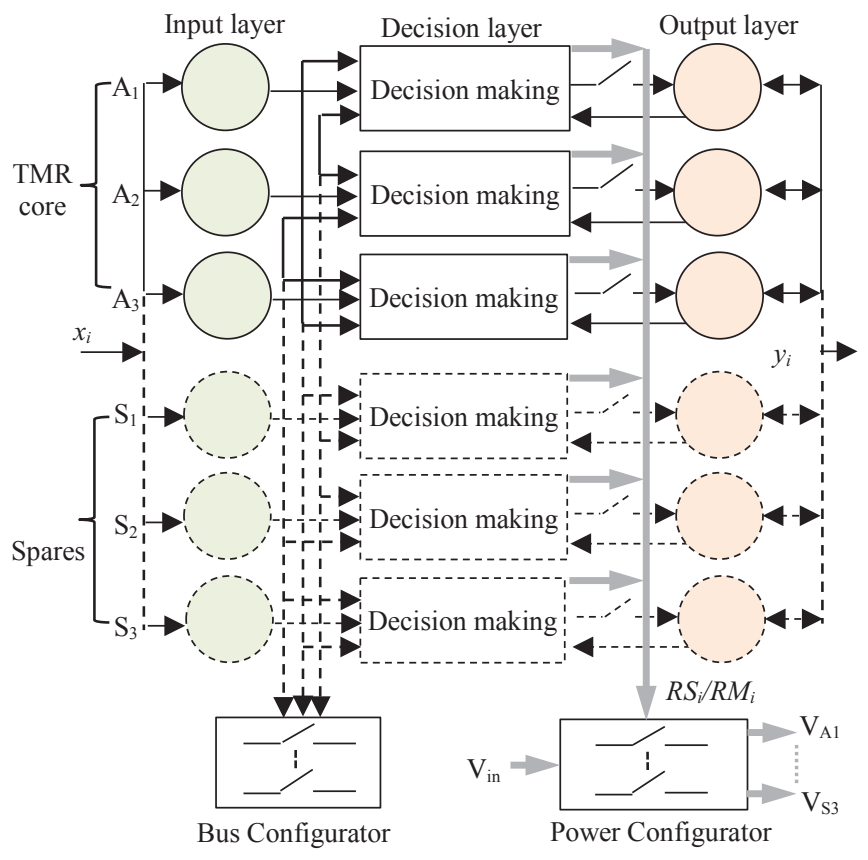

Fig. 2. The proposed rad-hardening architecture

timely power off reset can be effective against radiation damages, in this work, a radiation-tolerant architecture, shown in Fig.2, is developed to prolong both device and system life through independent built-in redundant channels, on-line fault detection, $r$ eal-time $\mathrm{p}$ reventive $\mathrm{r}$ emedial actions, and $\mathrm{r}$ apid power off/on recovery, as well as reduction of common-mode damage modes. $T$ he ar chitecture co nsists of an act ive triple modular $r$ edundancy ( TMR) co re with spare $u$ nits for replacement of the failed active one. B oth measurements and self-diagnosis functions are accomplished in the TMR core.

Each ch annel can b e d ivided i nto t hree 1 ayers: t he i nput layer, the decision layer, and the output layer. Self-diagnostic functions, s uch as fault d etection, fault d iagnosis, p rognostic assessment, and reconfiguration suggestions, are accomplished in $t$ he $d$ ecision 1 ayer. $T$ he $d$ ecision layer has $t$ wo $t$ ypes of buses: an internal bus, which is used to exchange information with o ther c hannels; a nd a $\mathrm{n} I O$ bus, which is us ed for the master selection. All buses are independent, so other channels 
will work normally when one channel fails or has faults. More specifically, a "configurator" is designed to guarantee that the system o nly ever has three channels working simultaneously and $\mathrm{i} \mathrm{s} b$ uilt with $\mathrm{p}$ assive $\mathrm{d}$ evices, $\mathrm{s}$ uch a $\mathrm{s} r$ esistance, capacitance, an $\mathrm{d} n$ on-electronic $\mathrm{r}$ elays, et c., which ar e not sensitive to ionizing radiation. The configurator therefore can withstand a high level radiation.

The ope rating principle of the proposed s ystem works a s follows: when one channel has faults or fails to operate, which will be d etected by the function of s elf-diagnosis and/or the function e xternal-diagnosis; then, $\mathrm{d}$ ecision-making units i $\mathrm{n}$ other channels will generate the reconfiguration suggestions to cut power supply in a timely manner and its space channel will power-on to form a new T MR c ore. A number of radiation tolerant strategies are involved in protecting the system when one ch annel en counters $r$ adiation $d$ amages. $T$ hese are summarized in Tab. I.

\section{Problem Statement}

The objective of this paper is to:

(1) To evaluate the effectiveness of the proposed radiation protection architecture; and

(2) To e stablish $r$ eliability a ssessment model against radiation damages.

\section{EVALUATION OF RADIATION PROTECTION}

\section{A. Notations}

$u \quad$ the attenuation coefficient of shielding material

$u_{l} \quad$ the li near attenuation $\mathrm{c}$ oefficient o $\mathrm{f}$ shielding material

$p \quad$ the density of shielding material

$d \quad$ the shielding material thickness

I the intensity after passing the shielding thickness $d$

$I_{0} \quad$ the original intensity

$B$ the build-up factor, is greater than 1

$E$ the energy of the gamma radiation

\section{B. Attenuation of Gamma Radiation}

When $\mathrm{g}$ amma $\mathrm{r}$ adiation $\mathrm{p}$ asses $\mathrm{t}$ hrough a material under conditions of a 'good' geometry, as shown in Fig.3, a straightline relationship between the logarithm of the intensity and the thickness of the shielding can be illustrated as follows [11]:

$$
I=I_{0} e^{-u d} .
$$

The linear attenuation coefficient $(u)$ is the probability per unit $t$ hickness $t$ hat $p$ articles interact with the $m$ aterial. This value is dependent upon the atomic number $Z$ of the material and its density $(p)$. This relation can also be described through the use of the linear attenuation coefficient as follows [12]:

$$
I=I_{0} e^{-\left(u_{l} / p\right) \cdot(p d)} .
$$

\section{Build-up Factor}

However, under conditions of a 'poor' geometry, as shown
TABLE I

\begin{tabular}{|c|c|}
\hline $\begin{array}{c}\text { Tolerant } \\
\text { strategies }\end{array}$ & Description \\
\hline $\begin{array}{l}\text { Hardware } \\
\text { selection }\end{array}$ & $\begin{array}{l}\text { To investigate radiation hardness of different } \\
\text { semiconductor technologies and devices; and to select } \\
\text { COTS components with high radiation resistance. }\end{array}$ \\
\hline Diversity & $\begin{array}{l}\text { Enforcing differences, such as different semiconductor } \\
\text { technologies b ut functionally e quivalent components, } \\
\text { different s oftware a nd a lgorithms fo } \mathrm{rt} \text { he s ame } \\
\text { function, etc., are applied to achieve the diversity. }\end{array}$ \\
\hline $\begin{array}{l}\text { Multi-processor } \\
\text { cooperation }\end{array}$ & $\begin{array}{l}\text { Redundancy communication bu ses a nd } I O \text { checking } \\
\text { bus; w hen o ne c hannel h as non-responsive fa ilure or } \\
\text { wrong messages, it will be reset or power off. }\end{array}$ \\
\hline $\begin{array}{l}\text { Self-test } \\
\text { technology }\end{array}$ & $\begin{array}{l}\text { Self-test techniques, s uch a s monitoring voltage a nd } \\
\text { current, C PU self-checking, et c.; the } \mathrm{r} \text { ecovery } \\
\text { strategies will be triggered when they are out of range. }\end{array}$ \\
\hline Watchdog timer & $\begin{array}{l}\text { Combined } \mathrm{w} \text { ith } \mathrm{h} \text { ardware watchdog a nd s oftware } \\
\text { watchdog. }\end{array}$ \\
\hline $\begin{array}{l}\text { Modular } \\
\text { software design }\end{array}$ & $\begin{array}{l}\text { Many modules with different functions, error detection } \\
\text { and correction are used for the recovery strategies. }\end{array}$ \\
\hline $\begin{array}{l}\text { Prognostic } \\
\text { assessment }\end{array}$ & $\begin{array}{l}\text { Accurately } \mathrm{p} \text { rediction } \mathrm{o} \mathrm{ft} \text { he } \mathrm{c} \text { ircuit performance } \\
\text { according to present measurement and the analysis of } \\
\text { devices } \mathrm{r} \text { esponses, } \mathrm{t} \text { hen } \mathrm{m} \text { ake a d ecision } \mathrm{t} \text { o } \mathrm{t} \text { he } \\
\text { reconfigurator. }\end{array}$ \\
\hline $\begin{array}{l}\text { Fault detection } \\
\text { and diagnosis }\end{array}$ & $\begin{array}{l}\text { Online an alysis of } r \text { adiation } r \text { esponses of d evices and } \\
\text { circuits to timely diagnose the radiation fault for fast } \\
\text { recovery. }\end{array}$ \\
\hline
\end{tabular}

SUMMARY OF RADIATION-TOLERANT STRATEGIES

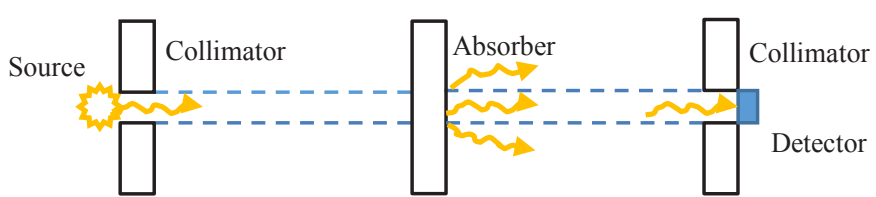

Fig. 3. Measurement of the attenuation of gamma radiation under conditions of 'good' geometry [11]

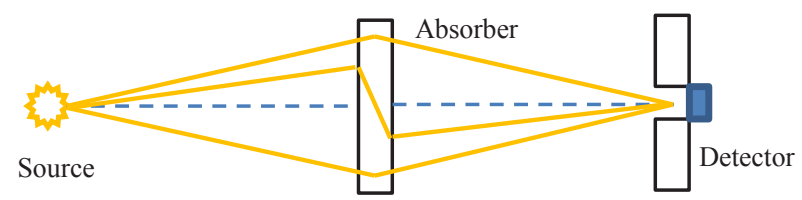

Fig. 4. G amma $\mathrm{r}$ adiation attenuation under $\mathrm{c}$ onditions o $\mathrm{fb}$ road beam geometry [11].

in $\mathrm{F}$ ig.4, $\mathrm{E}$ qn. ( 1) $\mathrm{u}$ nderestimates $\mathrm{t}$ he $\mathrm{r}$ equired s hielding thickness. The shielding thickness can be estimated by the use of a build-up factor $(B)$, which is defined as the $r$ atio of the intensity of the radiation at any point in a beam to the intensity of the primary radiation only at that point; it can be a function of the total attenuation coefficient, the thickness of shielding material, an $\mathrm{d} t$ he e nergy o $\mathrm{ft}$ he $\mathrm{g}$ amma $\mathrm{r}$ adiation [ 10-13]. Eqn.2 can, therefore, be estimated by Eqn.3 [11].

$$
I=B(u d, E) \cdot I_{0} \cdot e^{-\left(u_{l} / p\right) \cdot(p d)} .
$$

Build-up factors have been calculated for different levels of gamma e nergies a nd for va rious s hielding materials, which can be found in "American National Standard for Gamma-Ray Attenuation Coefficients and Buildup Factor for Engineering Materials", ANSI/ANS-6.4.3-1991 [14]. 


\section{Calculation of Shielding Thickness}

As previous discussion, with the given radiation source, the given $\mathrm{r}$ adiation d ose $\mathrm{r}$ ate, a nd the known shielding material, based on E qn.1 to E qn.3, $t$ he $r$ equired s hielding $t$ hickness under a poor geometry can be calculated as follows:

$$
d=\ln \left(B \cdot I_{0} / I\right) / u \text {. }
$$

According to this equation, various shielding materials can be $\mathrm{s}$ elected an $\mathrm{d}$ co mpared, $\mathrm{t}$ hen the $\mathrm{d}$ esigned shielding thickness $\mathrm{c}$ an $\mathrm{b}$ e a lso evaluated to ach ieve $\mathrm{t}$ he $\mathrm{d}$ esign objective, which is to reduce the to tal dose to less than $20 \mathrm{~K}$ $\operatorname{Rad}(\mathrm{Si})$

\section{RELIABILITY ASSESSMENT}

\section{A. Attenuation of Gamma Radiation}

$R(t) \quad$ reliability of an item at time $t$

$R_{i j}(t) \quad$ reliability of the $j$ th layer in the channel $i$ at time $t$

$R_{C_{i}}(t)$ reliability of the channel $i$ at time $t$

$R_{S}(t) \quad$ reliability of the proposed system at time $t$

$R^{\prime}(t) \quad$ reliability of an ite $m$ at time $t$ under to tal radiation dose $D_{t}$

$R^{\prime}{ }_{i j}(t)$ reliability of the $j$ th layer in the channel $i$ at time $t$ under total radiation dose $D_{t}$

$R^{\prime}{ }_{C}(t)$ reliability o $\mathrm{ft}$ he $\mathrm{c}$ hannel $i$ at ti me $t$ under to tal radiation dose $D_{t}$

$R^{\prime}{ }_{S}(t) \quad$ reliability of the p roposed s ystem at ti me $t$ under total radiation dose $D_{t}$

$m \quad$ the number of redundant channels in the system

$\lambda$ the failure rate of an item

$\lambda_{i j} \quad$ the failure rate of the $j$ th layer in channel $i$

$\lambda_{i j_{k}} \quad$ the failure rate of $k$ th component of the $j$ th layer in channel $i$

$\Delta \quad$ radiation degradation factor $\mathrm{u}$ nder to tal $\mathrm{r}$ adiation dose $D_{t}$

$P_{0}$ the value o f a c haracteristic $\mathrm{p}$ arameter $\mathrm{b}$ efore exposure

$P_{t} \quad$ the value o $\mathrm{ft}$ he $\mathrm{c}$ haracteristic $\mathrm{p}$ arameter af ter a total radiation dose $D_{t}$

$P_{f} \quad$ the value of the characteristic parameter at failure of total radiation dose $D_{f}$

\section{B. Assessment Model}

The reliability function $R(t)$ represents the probability that an item (component, subsystem, or system) will perform the designed $\mathrm{f}$ unctions o ver a given $\mathrm{t}$ ime i nterval $[0, t]$ under specific o perating e nvironmenta nd c onditions [ 15]. Conventional a nalysis methods f or system $r$ eliability are dependent on probabilistic a pproaches, which incorporate all failure events as random events. These methods are based on two fundamental a ssumptions: (1) bi nary s tate a ssumptions, where the system can only be in either of the two states (fully functioning or fully failed); and (2) probability a ssumptions, where the system failure behavior is fully characterized by the probability measures [ 16]. H owever, $t$ here ar e many uncertainties when a de vice or s ystem works i n a harsh environment, which may include the strong levels of radiation, extremely high t emperature, a nd hi gh humidity, e tc.; t hose uncertainties challenge the assumptions in the "conventional" reliability a nalysis o $\mathrm{ft}$ he co mponents an $\mathrm{d} i$ ncrease $\mathrm{t}$ he probability of $\mathrm{f}$ ailure of the $\mathrm{i}$ tem ( component, $\mathrm{s}$ ubsystem, and/or system) [17]. Therefore, the analysis employed by the conventional methods may not represent a realistic situation in a harsh environment. Radiation effects should be considered in the reliability analysis.

This work first e stablishes the a ssessment model for $\mathrm{n}$ onradiation conditions through the failure rate, in order to obtain the $\mathrm{r}$ eliability o $\mathrm{ft}$ he $\mathrm{p}$ roposed ar chitecture $\mathrm{u}$ nder $\mathrm{r}$ adiation conditions. $\mathrm{T}$ he f ailure $\mathrm{r}$ ate $\lambda(t)$ of a $\mathrm{n} \mathrm{i}$ tem ex presses $\mathrm{t}$ he "possibility to failure" of the item after time $t$ has passed [15]. It is estimated from the mean number of failures per unit time, which can be expressed by failure in time (FIT) as follows:

\section{$1 F I T=10^{-9}$ failure / hour}

The reliability $R(t)$ of the item can then be determined from the failure $\mathrm{r}$ ate $\lambda(t)$ with the $\mathrm{c}$ onsideration of $R(0)=1$ as follows [15]:

$R(t)=e^{-\int_{0}^{t} \lambda(\tau) d_{\tau}}$

Assuming that the failure $\mathrm{r}$ ate is independent of time $(t)$, then $\lambda(t)=\lambda$, Eqn.5 can be simplified to [15]

$R(t)=e^{-\lambda t}$

Considering that the pr oposed a rchitecture c onsists of a $\mathrm{n}$ input la yer, a d ecision la yer, a nd a n o utput la yer; a nd th e reliability o $\mathrm{fd}$ iversified $\mathrm{c}$ hannels ar e al $1 \mathrm{~d}$ ifferent, the reliability of the $j$ th layer in the channel $i$, which consists of $n_{l}$ components, can be evaluated using the formula.

$R_{i j}(t)=e^{-\lambda_{i j} t}=\prod_{k=1}^{n_{l}} e^{-\lambda_{k} t}=e^{-\sum_{k=1}^{n_{l}} \lambda_{i j k} t}(i=1, \ldots, m ; j=1,2,3)$.

The reliability of the channel $i$ can be described as follows:

$R_{C_{i}}(t)=e^{-\lambda_{C_{i}} t}=\prod_{j=1}^{3} e^{-\lambda_{i j} t}=e^{-\sum_{j=1}^{3} \lambda_{i j} t}(i=1,2,3)$.

Under non-radiation conditions, the reliability model of the proposed architecture can then be described as follows: 
$R_{S}(t)=\left(1-\prod_{i=1}^{m}\left(1-R_{i 1}(t)\right)\right) \times\left(1-\prod_{i=1}^{m}\left(1-\left(R_{i 2}(t) \times R_{i 3}(t)\right)\right)\right)$.

Specifically, as $\mathrm{p}$ reviously discussed, cas es o f al $1 \mathrm{t}$ hree channels s imultaneouslye ncountering failures ar e not considered i $\mathrm{nthis}$ work, co mmon ca use failure ( $\mathrm{CCF}$ ) i s therefore not considered.

\section{Radiation Degradation Factor}

To ta ke $\mathrm{r}$ adiation e ffects in $\mathrm{c}$ onsideration $\mathrm{i} \mathrm{n}$ system reliability analysis, a new method for electronic systems has been $d$ eveloped i $n$ [ 17], [ 118$]$. This method us es $r$ adiation degradation factors $(\Delta)$, instead of the usual failure rate data of an ite $\mathrm{m}$ in $\mathrm{t}$ he $\mathrm{r}$ eliability model, a $\mathrm{s}$ in put to $\mathrm{d}$ escribe th $\mathrm{e}$ radiation response of this item under a total radiation dose $D_{t}$, which will lie in the in terval $[0,1]$ and can $b$ e d efined as follows:

$$
\Delta=\min \left\{\left|\left(P_{0}-P_{t}\right) /\left(P_{0}-P_{f}\right)\right|, \quad 1\right\} .
$$

A d etailed d escription of $t$ he $r$ adiation de gradation factor can be found in [18]:

$$
\Delta=\left\{\begin{array}{cl}
\left(P_{0}-P_{t}\right) /\left(P_{0}-P_{f}\right) & \text { for } P_{0} \geq P_{t}>P_{f} \text { or } P_{0} \leq P_{t}<P_{f} \\
0 & \text { for } P_{t}>P_{0}>P_{f} \text { or } P_{t}<P_{0}<P_{f} \\
1 & \text { for } P_{0}>P_{f}>P_{t} \text { or } P_{0}<P_{f}<P_{t}
\end{array} .\right.
$$

Previous $r$ esearch [ 17], [1 8] h as d erived the parameter values of radiation d egradation from real $r$ adiation te st $d$ ata; with radiation degradation function which are used to describe how the material and/or co mponents $\mathrm{c}$ hange their p roperties under gi ven $\mathrm{r}$ adiation $\mathrm{c}$ onditions. Radiation d egradation functions are separated into three categories in [18], as shown in Fig.5:

1) Piece-wise li near $r$ adiation degradation $\mathrm{f}$ unction, with logarithmic dose values and linear parameter values;

2) Linear radiation degradation function in the en tire range of exposure; and

3) Constant $r$ adiation degradation function. The va lue 1 is up to $D_{f}$, and the value 0 is a ssumed to fail a bruptly at the threshold dose.

Due to the fact that semiconductor components may have a number $\left(n_{p}\right)$ of critical parameters, in this study, the radiation degradation $\mathrm{f}$ actor i s d efined as $\mathrm{t}$ he mean $\mathrm{v}$ alue o $\mathrm{ft}$ hose degradation $\mathrm{f}$ actors of all critical $\mathrm{p}$ arameters, which ca $\mathrm{n}$ be described as follows:

$\Delta=\frac{\sum_{i=1}^{n_{p}} \min \left\{\left|\left(P_{i_{0}}-P_{i_{t}}\right) /\left(P_{i_{0}}-P_{i_{f}}\right)\right|, \quad 1\right\}}{n_{p}}$.

The reliability $\left(R^{\prime}(t)\right)$ of the item under total radiation dose

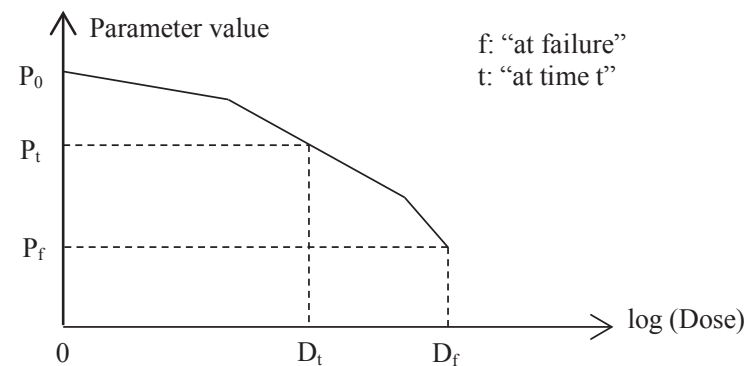

(a) Piece-wise linear radiation degradation function

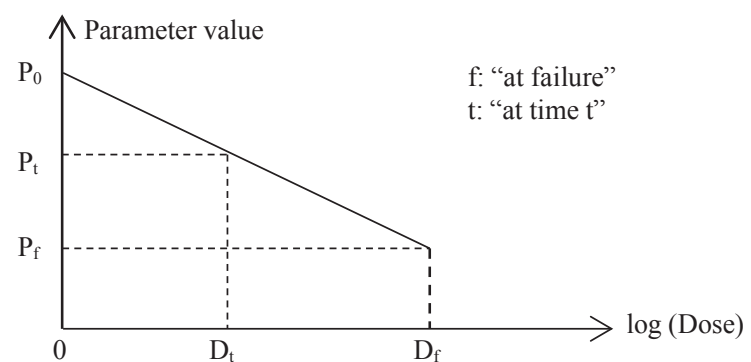

(b) Linear curve in the entire range of exposure

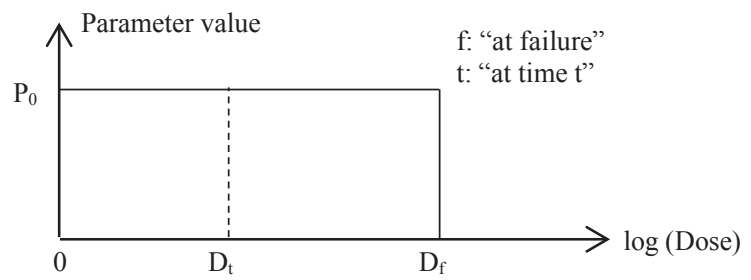

(c) Simple radiation degradation function

Fig. 5. Radiation degradation function [18].

$D_{t}$ can then be described in Eqn.13.

$R^{\prime}(t)=(1-\Delta) \cdot R(t)=(1-\Delta) \cdot e^{-\lambda t}$.

The r eliability of the $j$ th layer in the ch annel $i$ under the total radiation dose $D_{t}$ can be evaluated in Eqn. 14 .

$R_{i j}^{\prime}(t)=\prod_{k=1}^{n_{l}}\left(1-\Delta_{k}\right) e^{-\lambda_{k} t}(i=1, \ldots, m ; j=1,2,3)$.

Assuming that the channel $i$ consists of $n_{c}$ components, the reliability of the channel $i$ under total radiation dose $D_{t}$ can be described in Eqn.15.

$R^{\prime} C_{i}(t)=\prod_{k=1}^{n_{c}}\left(1-\Delta_{k}\right) e^{-\lambda_{k} t}(i=1,2,3)$.

Based on E qn.5 a nd E qn.15, the r eliability model of the redundant architecture mentioned in Fig.2 under total radiation dose $D_{t}$ can be derived as Eqn. 16 .

$R_{S}^{\prime}(t)=\left(1-\prod_{i=1}^{m}\left(1-R_{i 1}^{\prime}(t)\right)\right) \times\left(1-\prod_{i=1}^{m}\left(1-\left(R_{i 2}^{\prime}(t) \times R_{i 3}^{\prime}(t)\right)\right)\right)$. 


\section{A CASE STUdy}

\section{A. Development and Evaluation of Radiation Protection \\ 1) Radiation Shielding}

To en hance the radiation tolerance, the proposed radiationtolerant architecture in Fig.2 is further protected by a structure of $\mathrm{r}$ adiation s hielding a s illu strated in F ig. 6 to in crease th $\mathrm{e}$ radiation to lerance while to a void c ommon-mode da mage. This design consists of three protection layers, with the second and th ird la yers (Fig.6 (b)) in serted i nto th e first p rotective layer (Fig.6 (a)). T he th ird la yer is s maller than the second, and each layer is composed of different materials, which are determined $b$ y the $\mathrm{p}$ articular semiconductor d evices $\mathrm{u}$ sed in the electronic system. The layout of the proposed architecture is also illustrated in Fig.6 (c).

The d etailed $\mathrm{p}$ arameters of $\mathrm{r}$ adiation $\mathrm{s}$ hieling ar $\mathrm{e} l$ isted as follows:

- The material of the first shielding is copper, the size is $26 \mathrm{~cm} * 26 \mathrm{~cm} * 20 \mathrm{~cm}$, and its thickness is $1 \mathrm{~cm}$;

- The material of the second shielding is lead, the size is $24 \mathrm{~cm} * 24 \mathrm{~cm} * 18 \mathrm{~cm}$, and its thickness is $6 \mathrm{~cm}$; and

- The material o $\mathrm{ft}$ he $\mathrm{t}$ hird shielding i s $\mathrm{t}$ ungsten, $\mathrm{t}$ he diameter is $4 \mathrm{~cm}$, and its thickness is $1 \mathrm{~cm}$.

\section{2) The Evaluation of Radiation Shielding}

As illustrated in Fig.6, with different shielding materials for different la yers, $s$ hielding $t$ hickness, $r$ adiation a ngle, a nd radiation locations, a $1 \mathrm{~h}$ have different $\mathrm{e}$ ffects on the radiation exposure e xperienced b y e lectronic s ystems $\mathrm{i} n \mathrm{t}$ he six identified ar eas, as $\mathrm{s}$ hown in $\mathrm{F}$ ig.6(a) $\left(A_{1}-A_{3}, S_{1}-S_{3}\right)$. Using Co-60 as a r adiation s ource, t he cap ability o $\mathrm{ft}$ he protections can be summarized as follows:

- Under th e c ondition with d ose r ate $2700 \mathrm{~Sv} / \mathrm{h}$, a t th e given $24 \mathrm{~h}$, the highest total dose in six areas is about $100 \mathrm{~K}$ $\operatorname{Rad}(\mathrm{Si})$;

- Under th e c ondition with d ose r ate $1350 \mathrm{~Sv} / \mathrm{h}$, a t th e given $24 \mathrm{~h}$, the highest total dose in six areas is about $50 \mathrm{~K} \mathrm{Rad}$ (Si);

- Under the condition with dose rate $530 \mathrm{~Sv} / \mathrm{h}$, at the given $24 \mathrm{~h}$, the highest total dose in six areas is about $24 \mathrm{~K} \mathrm{Rad}(\mathrm{Si})$;

- Under the condition with dose rate $70 \mathrm{~Sv} / \mathrm{h}$, at the given $24 \mathrm{~h}$, the highest total dose in six areas is about $2.6 \mathrm{~K} \mathrm{Rad}(\mathrm{Si})$.

\section{B. Design and Assessment of Redundant Wireless Monitoring Devices}

\section{1) Implementation of Monitoring Devices}

As pr eviously mentioned, T MR c ore of t he de veloped radiation-tolerant a rchitecture $\mathrm{c}$ onsists o f a $\mathrm{n}$ i nput la yer, a decision 1 ayer, an $\mathrm{d}$ an o utput 1 ayer. $\mathrm{M}$ ore s pecifically, the input layer consists of input sources, a s ource encoder, and a channel en coder; the d ecision 1 ayer co nsists of the d ecisionmaking unit; a nd t he o utput 1 ayer $\mathrm{c}$ onsists o $\mathrm{fa} d$ igital modulator and transceiver. For simplity, only one temperature sensor is considered herein.

Component selection is an important step in the design phase of C OTS-based $\mathrm{r}$ ad-hardened s ystems. $\mathrm{R}$ adiation e ffects a re different on different devices, circuits and systems, depending on $\mathrm{t}$ heir $\mathrm{u}$ nique materials, $\mathrm{s}$ tructure, manufacturing

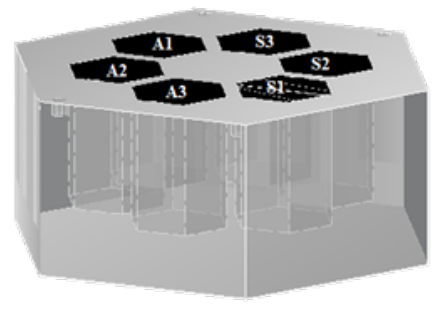

(a)

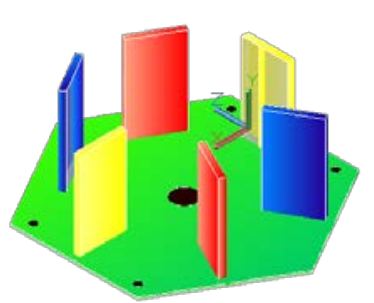

(c)

Fig. 6. (a ), (b ) The proposed s tructure o $\mathrm{fr}$ adiation p rotection. ( c) The mounting of electronic circuits in the proposed radiation-tolerant architecture.

technologies, a nd a pplications. I $\mathrm{n} t$ his work, $\mathrm{r}$ eferring $\mathrm{t} \mathrm{o}$ radiation test $\mathrm{d}$ ata from $\mathrm{t}$ he $\mathrm{N}$ ASA $\mathrm{G}$ oddard $\mathrm{S}$ pace $\mathrm{F}$ light Center [ 19], al 1 wireless c hannels an $d t$ heir s pares a re implemented $\mathrm{w}$ ith diversity $\mathrm{h}$ ardware, $\mathrm{w}$ hose detailed implementation and related in formation are listed in Table II. Specifically, $\mathrm{t}$ hose c omponents $\mathrm{s}$ uch a $\mathrm{s} r$ esistance, capacitance, et c., ar e $\mathrm{n}$ ot $\mathrm{l}$ isted $\mathrm{d}$ ue $\mathrm{t}$ o $\mathrm{t}$ heir $\mathrm{r}$ obustness to radiation.

\section{2) The Reliability Assessment of Monitoring Device}

In the a ssessment p rocess for s ystem r eliability in E qn.16, the reliability model considers only the factor of total radiation dose. The difficulty of the a ssessment lies in determining the degradation $\mathrm{f}$ actors $\mathrm{f}$ or $\mathrm{s}$ emiconductor $\mathrm{d}$ evices. $\mathrm{M}$ ost o $\mathrm{f}$ radiation degradation factors under different radiation doses in this study c ome from NASA G oddard S pace $\mathrm{F}$ light $\mathrm{C}$ enter radiation te st data [19], which ar e a vailable from o n-line resources; others are derived from the ex isting literature [2022].

In this work, the failure rates of semiconductor components listed in Column (7) of Table II come from the online resources o $\mathrm{ft}$ heir manufacturers, while $\mathrm{t}$ hose $\mathrm{r}$ adiation degradation factors 1 isted in Column (8) to (11) of T able II. Specifically, $P_{f}$ of s ome co mponents ar e n ot ea sy t o o btain from the NASA d atabase and 1 iterature, an d are instead derived from specification limits of electronic parameters.

According t o E qn.5 to E qn.16, u nder f our d ifferent to tal radiation doses (10 K Rad ( $\mathrm{Si}), 20 \mathrm{~K} \mathrm{Rad}(\mathrm{Si}), 50 \mathrm{~K} \mathrm{Rad}(\mathrm{Si})$, $100 \mathrm{~K} \mathrm{Rad}(\mathrm{Si})$ ), th e s ystem r eliabilities of th e d eveloped wireless monitoring node a re s hown in $\mathrm{F}$ ig.7. It s hows that system reliability decreases significantly when total radiation dose increases. Moreover, according to the compassion result for the reliabilities of different channels $(A 1 / S 1, A 2 / S 2, A 3 / S 3)$ and redundant systems $(F T(m=3), F T(m=6))$, also shown in Fig.7, the reliability of the developed redundant architecture is much improved than those of non-redundant $\mathrm{c}$ hannels under the given radiation conditions. 
TABLE II

THE IMPLEMENTATION OF RADIATION-TOLERANT WIRELESS MONITORING DEVICE

\begin{tabular}{|c|c|c|c|c|c|c|c|c|c|c|c|c|}
\hline Channel & Function & Type & Q. & Tech. & Manu. & FIT & R.D.F. & $\begin{array}{c}\Delta \\
10 \mathrm{~K} \\
\end{array}$ & $\begin{array}{c}\Delta \\
20 \mathrm{~K} \\
\end{array}$ & $\begin{array}{c}\Delta \\
50 \mathrm{~K} \\
\end{array}$ & $\begin{array}{c}\Delta \\
100 \mathrm{~K} \\
\end{array}$ & $\begin{array}{c}\text { Radiation } \\
\text { effects }\end{array}$ \\
\hline \multirow{10}{*}{$A 1 \& S 1$} & \multirow{3}{*}{$\begin{array}{l}\text { Source } \\
\text { encoder }\end{array}$} & NPN BJT & 1 & Bipolar & Semicoa & 2.45 & $\mathrm{~A}$ & 0.194 & 0.3201 & 0.4267 & 0.4591 & TID \\
\hline & & $\begin{array}{l}\text { Voltage } \\
\text { reference }\end{array}$ & 1 & Bipolar & $\mathrm{TI}$ & 3.30 & A & 0.0774 & 0.1010 & 0.2104 & 0.3432 & SEU, SEL, TID \\
\hline & & OP amp & 3 & Bipolar & $\begin{array}{l}\text { National } \\
\text { Semi. }\end{array}$ & 1.85 & A & 0.0208 & 0.0365 & 0.0383 & 0.0365 & SEL, SET, TID \\
\hline & \multirow{2}{*}{$\begin{array}{l}\text { Channel } \\
\text { encoder }\end{array}$} & $\begin{array}{l}\text { Voltage } \\
\text { reference }\end{array}$ & 1 & Bipolar & $\mathrm{TI}$ & 3.30 & A & 0.0642 & 0.1099 & 0.5158 & 0.5786 & SEU, SEL, TID \\
\hline & & $\mathrm{AD}$ & 1 & Bipolar & $\begin{array}{l}\text { Analog } \\
\text { Devices }\end{array}$ & 0.20 & $\mathrm{~A}$ & 0.0178 & 0.0486 & 0.0633 & 0.0649 & $\begin{array}{l}\text { SEU, SEL, } \\
\text { SEFI, TID }\end{array}$ \\
\hline & \multirow{2}{*}{$\begin{array}{l}\text { Decision } \\
\text { making\& } \\
\text { Digital } \\
\text { modulator }\end{array}$} & $\mathrm{E}^{2} \mathrm{PROM}$ & 1 & CMOS & Atmel & 2.2 & A & 0.0023 & 0.0244 & 0.1341 & 0.1326 & $\begin{array}{l}\text { SEU, SEL, } \\
\text { SEFI, TID }\end{array}$ \\
\hline & & $\begin{array}{c}\text { Micro } \\
\text { controller }\end{array}$ & 1 & CMOS & Microchip & 3.3 & $\mathrm{~A}$ & 0.0187 & 0.0465 & 0.1001 & 0.1179 & SEE, TID \\
\hline & \multirow{3}{*}{ Transceiver } & $\begin{array}{l}\text { Voltage } \\
\text { reference }\end{array}$ & 1 & Bipolar & Linear & 3.30 & $\mathrm{C}$ & 0.0000 & 0.0000 & 0.0000 & 0.0000 & SEU, SEL, TID \\
\hline & & Diode & 1 & Bipolar & Toshiba & 3.30 & A & 0.0000 & 0.0577 & 0.0145 & 0.0769 & SEU, SEL, TID \\
\hline & & $433 \mathrm{MHz} \mathrm{RF}$ & 1 & Bipolar & RFMD & 1.90 & A & 0.0395 & 0.0745 & 0.1503 & 0.1810 & SEE, TID \\
\hline \multirow{8}{*}{$A 2 \& S 2$} & \multirow{2}{*}{$\begin{array}{l}\text { Source } \\
\text { encoder }\end{array}$} & $\begin{array}{l}\text { Voltage } \\
\text { reference }\end{array}$ & 1 & BiCMOS & $\mathrm{TI}$ & 3.30 & A & 0.1510 & 0.0181 & 0.0087 & 0.0094 & SEU, SEL, TID \\
\hline & & OP amp & 3 & CMOS & $\begin{array}{l}\text { Analog } \\
\text { Devices }\end{array}$ & 0.28 & A & 0.0409 & 0.0770 & 0.2989 & 0.2168 & SEL, SET, TID \\
\hline & \multirow{3}{*}{$\begin{array}{l}\text { Channel } \\
\text { encoder }\end{array}$} & OP amp & 1 & CMOS & $\begin{array}{l}\text { Analog } \\
\text { Devices }\end{array}$ & 0.28 & $\mathrm{~A}$ & 0.2377 & 0.3964 & 0.6620 & 0.6537 & SEL, SET, TID \\
\hline & & $\begin{array}{l}\text { Voltage } \\
\text { reference }\end{array}$ & 1 & CMOS & TI & 3.30 & A & 0.1408 & 0.3371 & 0.3204 & 0.3846 & SEU, SEL, TID \\
\hline & & $\mathrm{AD}$ & 1 & BiCMOS & $\begin{array}{l}\text { Analog } \\
\text { Devices }\end{array}$ & 0.25 & A & 0.1735 & 0.1503 & 0.2741 & 0.3345 & SEE, TID \\
\hline & \multirow{2}{*}{$\begin{array}{l}\text { Decision } \\
\text { making\& } \\
\text { Digital } \\
\text { modulator }\end{array}$} & $\begin{array}{c}\text { Micro } \\
\text { controller }\end{array}$ & 1 & CMOS & Atmel & 5.60 & A & 0.0638 & 0.0654 & 0.0985 & 0.1190 & $\begin{array}{l}\text { SEU, SET, } \\
\text { SEL,SEFI,TID }\end{array}$ \\
\hline & & Logic gate & 1 & CMOS & $\mathrm{TI}$ & 0.50 & A & 0.133 & 0.0244 & 0.1850 & 0.2432 & SEU, SEL, TID \\
\hline & Transceiver & $433 \mathrm{MHz} \mathrm{RF}$ & 1 & CMOS & $\begin{array}{l}\text { Freescale } \\
\text { Semi. }\end{array}$ & 2.0 & A & 0.1026 & 0.1336 & 0.2310 & 0.2451 & SEE, TID \\
\hline \multirow{9}{*}{$A 3 \& S 3$} & \multirow{2}{*}{$\begin{array}{l}\text { Source } \\
\text { encoder }\end{array}$} & $\begin{array}{l}\text { Voltage } \\
\text { reference }\end{array}$ & 1 & HSCMOS & Allegro & 3.3 & A & 0.1408 & 0.3371 & 0.3204 & 0.3846 & SEU, SEL, TID \\
\hline & & OP amp & 3 & BiFET & TI & 0.2 & A & 0.0689 & 0.1551 & 0.3673 & 0.5151 & SEL, SET, TID \\
\hline & \multirow{3}{*}{$\begin{array}{l}\text { Channel } \\
\text { encoder }\end{array}$} & $\begin{array}{l}\text { Voltage } \\
\text { reference }\end{array}$ & 1 & TTL & $\begin{array}{l}\text { Analog } \\
\text { Devices }\end{array}$ & 3.3 & A & 0.0039 & 0.0216 & 0.0223 & 0.0644 & SEU, SEL, TID \\
\hline & & $\mathrm{AD}$ & 1 & $\mathrm{LC}^{2} \mathrm{MOS}$ & $\begin{array}{l}\text { Analog } \\
\text { Devices }\end{array}$ & 1.6 & A & 0.0181 & 0.0229 & 0.0246 & 0.0209 & SEE, TID \\
\hline & & OP amp & 2 & Hybrid & $\begin{array}{c}\text { MOTOR } \\
\text { OLA }\end{array}$ & 0.2 & A & 0.1360 & 0.0764 & 0.1757 & 0.2717 & SEL, SET, TID \\
\hline & \multirow{3}{*}{$\begin{array}{l}\text { Decision } \\
\text { making\& } \\
\text { Digital } \\
\text { modulator }\end{array}$} & $\begin{array}{l}\text { Micro } \\
\text { controller }\end{array}$ & 1 & TTL & SILICON & 2.26 & A & 0.0109 & 0.0134 & 0.0149 & 0.0168 & TID, SEU, SET \\
\hline & & Logic gate & 1 & TTL & $\mathrm{TI}$ & 3.3 & A & 0.0469 & 0.0494 & 0.0480 & 0.0724 & SEU, SEL, TID \\
\hline & & $433 \mathrm{MHz}$ RF & 1 & TTL & SILICON & 1.90 & A & 0.0479 & 0.0781 & 0.1108 & 0.1567 & SEE, TID \\
\hline & Transceiver & $\begin{array}{l}\text { Voltage } \\
\text { reference }\end{array}$ & 1 & BiMOS & $\mathrm{TI}$ & 3.3 & A & 0.0055 & 0.0269 & 0.0238 & 0.0646 & SEU, SEL, TID \\
\hline
\end{tabular}

R.D.F. (radiation degradation function) - A (piece-wise linear radiation degradation function), B(linear curve in the entire range of exposure), C (simple radiation degradation function) 


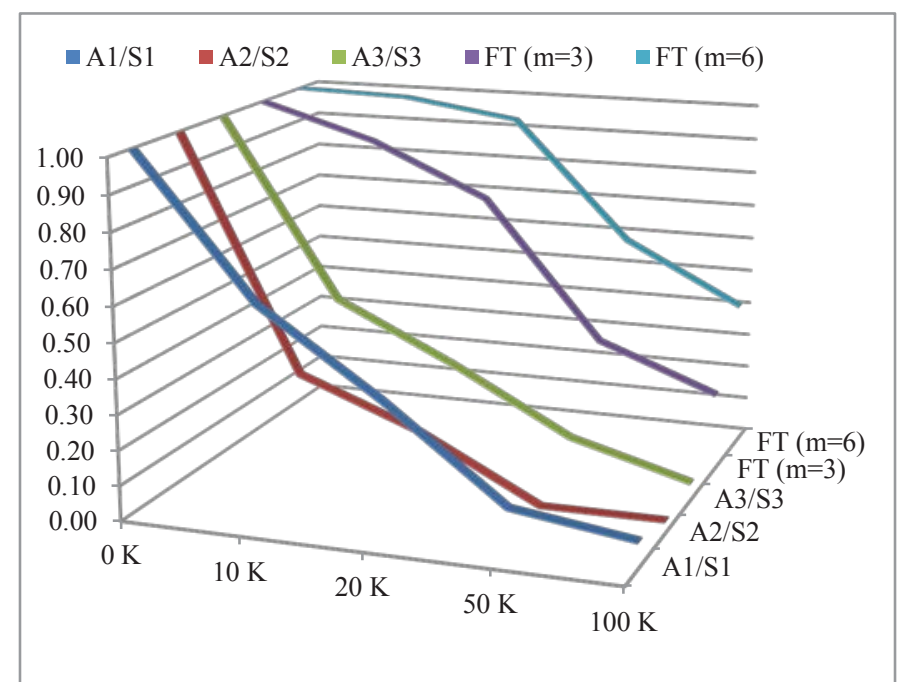

Fig. 7. The compassion of the reliability of the developed redundant system and no-redundant channels under the given total dose $(0,10 \mathrm{~K} \mathrm{Rad}(\mathrm{Si}), 20 \mathrm{~K}$ Rad (Si), 50 K Rad (Si), 100 K Rad (Si)).

In a s ummary, $\mathrm{r}$ adiation a ssessment o $\mathrm{ft}$ he $\mathrm{d}$ eveloped wireless d evice for $\mathrm{v}$ arious d ose $\mathrm{r}$ ates under $\mathrm{t}$ he gi ven $\mathrm{t}$ ime $(24 h)$ is illustrated in Fig. 8 . It shows that the reliability of the developed wireless device under dose rate $530 S v / h$ at $24 h$ is about $89.6 \%$. The d eveloped wireless d evice ca $n t$ herefore work in those high level radiation fields and meets the design objective.

\section{CONCLUSION}

In th is work, t he a ssessment of $\mathrm{r}$ adiation-tolerance o $\mathrm{f} \mathrm{a}$ wireless monitoring d evice is gi ven for hi gh 1 evel $r$ adiaiton fields, which is de veloped by using radiation protection and radundant techniques. The study results s how that to tal d ose can $\mathrm{b}$ e ef fectively $\mathrm{d}$ ecreased. In a ddition, th e $\mathrm{r}$ adiation assessment shows, under given radiation conditions (10 K Rad (Si), $20 \mathrm{~K} \operatorname{Rad}(\mathrm{Si}), 50 \mathrm{~K} \operatorname{Rad}(\mathrm{Si}), 100 \mathrm{~K} \operatorname{Rad}(\mathrm{Si})$ ), t he reliability of $\mathrm{t}$ he d eveloped s ystem (99.0\%, 94.2\%, $59.6 \%$, $42.3 \%$ ) can be much i mproved than those of $n$ on-redundant channels $(60.3 \%, 37.5 \%, 11.9 \%, 7.2 \%, 33.6 \%, 20.7 \%, 3.2 \%$, $3.4 \%$; and $48.5 \%, 32.5 \%, 14.3 \%, 5.1 \%$ ).

According to assessment studies, the developed device can work in high level radiation fields whose total dose is up to 1 $M \mathrm{Rad}(\mathrm{Si})$; and it $\mathrm{m}$ ay be available used in those conditions with total dose $10 \mathrm{MRad}(\mathrm{Si})$. It therefore provides an effective a nd eco nomical solution to o btain $\mathrm{u}$ p-to-date information during a severe accident in a nuclear power plant.

\section{ACKNOWLEDGMENT}

This work i s f inancially s upported b y t he $\mathrm{U}$ niversity Network of Excellence in Nuclear Engineering (UNENE) and the $\mathrm{N}$ atural $\mathrm{S}$ ciences an $\mathrm{d} \mathrm{E}$ ngineering $\mathrm{R}$ esearch $\mathrm{C}$ ouncil of Canada (NSERC).

\section{REFERENCES}

[1] H. M. Quinn, D. A. Black, W. H. Robinson, and S. P. Buchner, "Fault simulation and emulation tools to augment radiation-hardness assurance testing," IEEE Transactions on Nuclear Science, vol. 60, pp. 2119-2142, 2013.

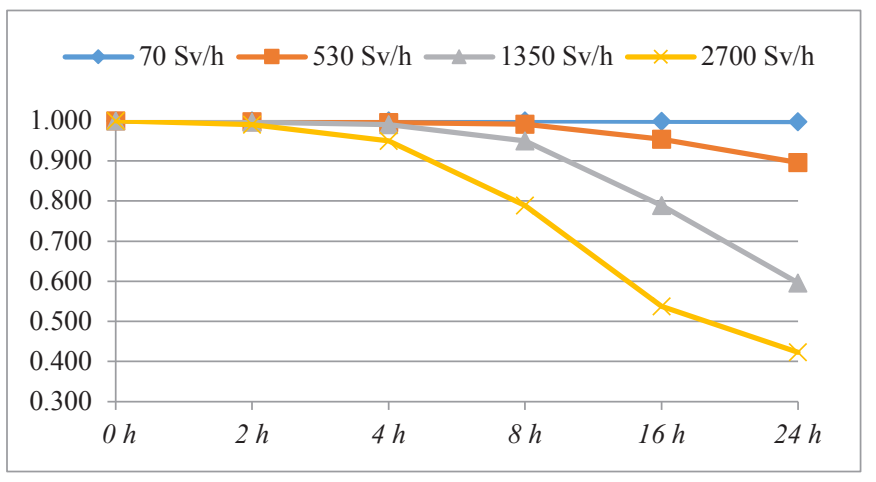

Fig. 8. Radiation assessment of the developed wireless device under various dose rates.

[2] R., Sharp, M. Decreton, "Radiation tolerance of components and materials in nuclear robot applications," Reliability Engineering and System Safety, vol. 53, pp. 291-299, 1996.

[3] https://www.theguardian.com/environment/2017/feb/03/fukushimadaiichi-radiation-levels-highest-since-2011-meltdown

[4] J.R. Srour, C.J. Marshall, and P.W. Marshall, "Review of displacement damage effects in silicon devices," IEEE Transactions on Nuclear Science, vol. 50, pp. 653-670, 2003.

[5] D.M. Fleetwood, "Total ionizing dose effects in MOS and low-doserate-sensitive linear-bipolar devices" IEEE Transactions on Nuclear Science, vol. 60, pp. 1706-1730, 2013.

[6] V. Ferlet-Cavrois, L.W. Massengill, and P. Gouker, "Single event transients in digital CMOS - a review," IEEE Transactions on Nuclear Science, vol. 59, pp. 1767-1790, 2013.

[7] Policy Elements Post-accident management in the event of nuclear accident," the Steering Committee for the Management of the PostAccident Phase of a Nuclear Accident (CODIRPA), 2012.

[8] G. C. M essenger and M. S. A sh, "The effects of $\mathrm{r}$ adiation el ectronic systems," Van Nostrand Reinhold, New York, 2nd edition, 1991.

[9] J. K, Shultis, R. E. Faw, "Radiation shielding technology," Health Physics, vol. 88, pp. 587-612, 2005.

[10] K.A. LaBel and M.M. Gates, "Single-event-effect mitigation from a system perspective," IEEE Transaction on Nuclear Science, vol. 43, pp. 654-660, 1996.

[11] https://www.nucleonica.com/

[12] E. Y ilmaz, H . B altas, E . K iris, i. Ustabas, U . Cevik, a nd A . M . E IKhayatt, "Gamma ray and netron shielding properties of some concrete materials," Annals of Nuclear Energy, vol. 38, pp. 9, 2011.

[13] C. Suteau and M. Chiron, "An iterative method for calculating Gammyray b uild-up $\mathrm{f}$ actors in $\mathrm{m}$ ulti-layer s hields," $\mathrm{R}$ adiation $\mathrm{P}$ rotection Dosimetry, vol. 116, pp. 489-492, 2005.

[14] American National S tandard for Gamma-Ray Attenuation Coefficients and Buildup Factors for Engineering Materials", ANSI/ANS-6.4.3-1991, 1991.

[15] Y. S ong an d B. W ang, "S urvey o $\mathrm{n} \mathrm{r}$ eliability o f p ower electronic systems," IEEE T ransactions on P ower E lectronics, vo 1. 28, pp. 59 1604, 2013.

[16] V. Ra vi, P . J . R eddy, an d H . J. Z immermann, "F uzzy g lobal optimization o f c omplex s ystem $r$ eliability," IEEE $\mathrm{T}$ ransactions o $\mathrm{n}$ Fuzzy Systems, vol. 8, pp. 241-248, 2000.

[17] K. Lauridsen, P. Christensen, a nd H. E. K ongso, "Assessment of the reliability of robotic systems for use in radiation environments," Reliability Engineering and System Safety, vol. 53, pp. 265-276, 1996.

[18] K. Lauridsen, M. Decreton, C. C. Seifert, and R. E. Sharp, "Reliability and $\mathrm{r}$ adiation tolerance of $\mathrm{r}$ obots f or $\mathrm{n}$ uclear a pplications," $\mathrm{T}$ he $\mathrm{f}$ inal report of C EC/TELEMAN p roject, N o. F I2T-CT90-0011, ENTOREL, 1996.

[19] https://radhome.gsfc.nasa.gov/radhome/tid.htm

[20] G. C. M essenger an d M. S . A sh, "The effects of r adiation el ectronic systems," Van Nostrand Reinhold, New York, 2nd edition, 1991.

[21] L. P. H oussay, " Robotics a nd $\mathrm{r}$ adiation $\mathrm{h}$ ardening in the $\mathrm{n}$ uclear industry," Master thesis, University of Florida, 2000.

[22] R. D . K ulkarni, a nd V . A garwal, " Reliability an alysis o f a m odern power s upply under nucler radiation e ffects," P ower Electronics and Drive Systems, PEDS 2003. 